\title{
ANALISIS KELAYAKAN PENGEMBANGAN PROYEK APARTEMEN CITRALAKE SUITES - CITRA GARDEN CITY
}

\author{
Noor Achyar Sulthoni \\ Program Studi Magister Manajemen Universitas Tarumanagara \\ noor.sulthoni@ciputra.co.id \\ Anas Lutfi \\ Program Studi Magister Manajemen Universitas Tarumanagara \\ Masuk : 21-06-2019, revisi : 27-08-2019 diterima untuk diterbitkan : 28-08-2019
}

\begin{abstract}
The population density in the capital has increased from year to years, this situation used by PT CD as a business tool in the property sector. A kind of research is needed to find out whether the development of this land is profitable or not, by conducting a Business Feasibility Analysis. Investment decision analysis is done by using 3 (three) main calculation methods. From the results of research conducted by the author, it is obtained as follows in :

1. In the payback period, sales are up to 2018 , reaching $60 \%$, so this project is feasible to be accepted

2. Net Present Value Analysis, From the results of calculations, NPV cash inflow is still far greater than the NPV cash outflow means that according to the NPV assessment that this project is considered very feasible to be carried out

3. The Internal Rate of Return (IRR) is a feasible project because the IRR is a normal and optimistic alternative. greater than the Weighted average cost of capital (WACC)

Based on the results of the analysis and calculations carried out by the author in relation to project, the general investment investment is considered very feasible and beneficial not only to the developer but also consumers who buy apartment units on the project. Paying attention to what has been analyzed and discussed, the author's suggestion is to re-check cashflow by considering finding alternative funding with an improved loan. so that the cost of capital is small and profits increase.
\end{abstract}

Abstrak : Kepadatan penduduk di Ibukota mengalami kenaikan dari tahun ketahun, situasi seperti ini dimanfaatkan oleh PT CD melalui anak perusahaannya PT CMM mencoba mengembangkan lahan seluas 1,2 ha di wilayah Jakarta Barat untuk dikembangkan menjadi hunian bertingkat bernama Apartemen Citralake Suites. Perlu dibuat semacam penelitian untuk mengetahui apakah pengembangan lahan ini menguntungkan atau tidak, dengan melakukan Analisis Kelayakan Bisnis. Selanjutnya analisis keputusan investasi dilakukan dengan menggunakan 3 (tiga) metoda utama kalkulasi, yaitu Payback Period, NPV (Net Present Value) dan IRR (Internal Rate of Return). Dari hasil penelitian yang telah dilakukan oleh penulis, diperoleh seperti berikut ini:

1. Secara payback period didapat penjualan sampai dengan tahun 2018 mencapai $60 \%$ dengan demikian proyek ini layak diterima.

2. Analisis Net Present Value, Dari hasil perhitungan, NPV cash inflow masih jauh lebih besar dari pada NPV cash outflow artinya menurut penilaian NPV bahwa proyek ini dianggap sangat layak untuk dilaksanakan.

3. Internal Rate of Return (IRR) proyek ini feasible karena yang kalau dicari IRR-nya alternatif normal dan alternatif optimis lebih besar dari Weighted average cost of capital (WACC)

Berdasarkan hasil analisis dan perhitungan yang dilakukan oleh penulis, maka secara umum investasi tersebut dianggap layak dan menguntungkan tidak hanya pihak developer tetapi juga 
konsumen yang membeli unit apartemen tersebut. Memperhatikan apa yang telah dianalisis dan dibahas, maka saran dari penulis adalah melakukan pengecekan kembali terhadap cashflow dengan mempertimbangan pencarian alternatif pendanaan dengan pinjaman yang ditingkatkan sehingga cost of capital kecil dan profit bertambah.

Keywords : Payback period, Net Present Value, Internal Rate of Return

\section{Pendahuluan}

Jakarta adalah ibukota Indonesia menjadi pusat perdagangan yang membuat banyak orang untuk mencari rejeki di kota ini, mengakibatkan populasi di Jakarta semakin bertambah dan kebutuhan akan pemukiman / tempat tinggal menjadi meningkat dari tahun ketahun. Jakarta sangat diminati untuk menjadi tempat pemukiman dan perkantoran karena asumsi sebagian besar orang bahwa peluang bisnis terbesar adalah di Ibukota Jakarta. Walaupun harga jual perkantoran dan pemukiman di Jakarta sangat mahal dan lalu lintas Jakarta sangat macet namun tidak menjadi penghalang bagi yang ingin tinggal dan berbisnis di Ibukota Jakarta.

Sampai saat ini usaha di bidang property masih memiliki prospek yang cerah dan mendatangkan banyak keuntungan. Karena kondisi saat ini sangatlah meyakinkan bahwa usaha dibidang property memiliki daya tarik tersendiri bagi investor. Tetapi banyak juga pengusaha mengalami kebangkrutan. Kenyataan ini menyadarkan bahwa kondisi bisnis perumahan seperti juga usaha di bidang lainnya mengalami fluktuasi. Fluktuasi industri ini berkaitan dengan kondisi perekonomian masyarakat. Bisnis perumahan adalah bisnis yang terakhir menikmati kenaikan pertumbuhan ekonomi. Hal ini disebabkan karena produk perumahan dapat digolongkan kepada barang investasi, jadi tidak merupakan prioritas utama dalam pembelanjaan. Di sisi lain proses pengadaannyapun membutuhkan waktu yang lama.

Seiring dengan perbaikan-perbaikan yang di lakukan oleh pemerintah disegala bidang, perlahan membuat perekonomian Indonesia mulai jalan dan menggeliat lagi. Salah satu strategi yang menguntungkan bagi para investor dan konsumen adalah tingkat suku bunga yang rendah, sehingga masyarakat lebih suka memutar uang dari pada menyimpan di Bank. Kondisi seperti ini juga memberikan keuntungan bagi para pelaku bisnis di bidang perumahan yang menyebabkan permintaan akan rumah meningkat.

Karena permintaan yang meningkat inilah penulis dalam tesis ini ingin melakukan suatu analisa awal, dalam rangka pemenuhan kebutuhan akan tempat tinggal, yang dapat membantu pengambilan keputusan investasi dibidang pengembangan atau pembangunan kawasan hunian kelas menengah keatas diwilayah Jakarta Barat. Analisa awal ini adalah merupakan suatu studi kelayakan pengembangan kawasan yang menentukan apakah gagasan bisnis ini bisa dipertimbangkan dan layak untuk dilaksanakan.

\section{Pokok Masalah}

Dalam tesis ini penulis akan mengulas mengenai strategi yang akan dilakukan oleh PT. CGC melalui anak perusahaannya PT. CMM dalam rangka pembukaan lahan baru seluas 1,2 ha untuk pengembangan kawasan hunian beserta fasilitas pendukungnya di daerah Kalideres di Jakarta Barat sebagai wujud ekspansi perusahaan dalam pengembangan unit usahanya. Proyek lahan baru seluas 1,2 ha ini dinamakan proyek Apartemen Citralake Suites.

Dilihat dari kondisi lingkungan dimana lokasi proyek berada dikelilingi oleh begitu banyak kompetitor, tentu akan menyebabkan adanya suatu rencana dan strategi pengembangan proyek yang matang dari PT. CMM dalam menghadapi persaingan di bisnis pengembangan properti. Apartemen Citralake Suites ini sudah terbangun 2 Tower, dari 4 Tower pada rencana awal. Dalam penelitian ini untuk menentukan acuan kapan Tower ke 3 akan di bangun dengan harga baru sesuai analisi studi dari 2 Tower yang sudah terbangun dan penjualannya. 


\section{Landasan Teori}

Menurut Kasmir dan Jakfar (2010) studi kelayakan bisnis adalah suatu kegiatan yang mempelajari secara mendalam tentang suatu kegiatan atau usaha yang akan dijalankan,untuk menentukan layak atau tidaknya suatu bisnis dijalankan.

Dalam suatu perekonomian yang kompleks seperti sekarang ini, orang harus mau menghadapi tantangan dan risiko untuk mengkombinasikan tenaga kerja, material, modal dan manajemen secara baik sebelum memasarkan suatu produk. Sebuah rencana investasi seharusnya diawali dengan suatu evaluasi kelayakan terhadap rencana investasi itu. Sekalipun terdapat bukti bahwa ada pengusaha yang berhasil melaksanakan proyek secara menguntungkan tanpa didahului evaluasi kelayakan, dan pengusaha lainnya justru gagal mengoperasikan proyek yang sebelumnya sudah diadakan evaluasi kelayakan oleh tim yang andal, namun evaluasi tersebut tetap penting artinya. Dari sudut perspektif rasional-objektif, tidaklah patut melakukan sesuatu yang mempunyai resiko yang besar berdasarkan persepsi untung-untungan. Investasi yang memiliki resiko besar seharusnya didahului oleh suatu studi kelayakan.

Dengan demikian studi kelayakan suatu bisnis merupakan penelitian tentang dapat tidaknya suatu bisnis (biasanya merupakan proyek investasi) dilaksanakan dengan berhasil. Suad Husnan, Suwarsono(2000). Pengertian keberhasilan ini mungkin bisa ditafsirkan berbeda-beda. Ada yang menafsirkan dalam artian yang terbatas, terutama dipergunakan oleh pihak swasta yang lebih berminat tentang manfaat ekonomis suatu investasi. Sedangkan dalam artian luas dapat dilihat atau dipertimbangkan berbagai faktor seperti manfaat bagi masyarakat luas yang bisa berwujud penyerapan tenaga kerja, pemanfaatan sumber daya yang melimpah dan sebagainya.

Pada proyek komersial, tumpuannya terletak pada kemampuan untuk memasarkan produk yang dihasilkan ke pasar yang telah direncanakan. Keberhasilan menjual produk yang dihasilkan menjadi wahana untuk menerima dana berupa arus kas masuk dari hasil penjualan. Dana hasil penjualan dimaksud berguna untuk memikul beban pengeluaran, sekaligus menghasilkan laba. Apabila salah satu, atau beberapa pasar mengalami perubahan, dan daya serap pasar terhadap produk yang dijual menurun, maka perusahaan akan menghadapi kesulitan dalam merealisasikan target arus kas masuk yang telah direncanakan. Selanjutnya, kejadian itu akan mengganggu operasi, bahkan mengancam terhentinya operasi perusahaan. Jika kenyataan tersebut dihadapi setelah proyek dilaksanakan, maka investor tidak mudah untuk menghentikan dan mengalihkan dana ke proyek lainnya. Hal itu antara lain disebabkan oleh sulitnya mengubah komitmen keuangan yang telah dibuat dengan pihak kreditur atau penyandang dana. Dengan demikian, keterlanjuran melakukan investasi yang belum dijamin keakuratan evaluasinya, berpotensi sangat menyulitkan di masa mendatang.

Memperhatikan uraian yang telah dikemukakan di atas, dapat disimpulkan beberapa kegunaan primer dari studi kelayakan. Suad Husnan, Suwarsono (2000), yakni :

1. Memandu pemilik dana untuk mengoptimalkan dana yang dimilikinya.

2. Memperkecil resiko kegagalan investasi, dan pada saat yang sama memperbesar peluang keberhasilan investasi yang bersangkutan.

3. Alternatif investasi teridentifikasi secara objektif dan teruji secara kuantitatif sehingga manajer puncak mudah mengambil keputusan investasi yang objektif.

4. Aspek terkait terungkap secara keseluruhan dan lengkap, sehingga penerimaan dan atau penolakan terhadap alternatif investasi didasarkan atas pertimbangan terhadap semua aspek proyek dan bukan hanya aspek finansial saja.

\section{Analisis}

Metode pemulihan investasi (payback period method) adalah suatu periode yang diperlukan untuk menutup kembali pengeluaran investasi (initial cash investment) dengan menggunakan aliran kas. Jadi payback periode merupakan rasio antara initial cash investment 
dengan cash inflow-nya yang hasilnya merupakan satuan waktu. Jangka waktu pemulihan modal adalah jangka waktu yang diperlukan untuk mengembalikan seluruh modal yang diinvestasikan.

Dalam analisis ini, yang diperhitungkan adalah rasio antara initial cash investment/cash outflow dengan cash inflow, yang hasilnya merupakan satuan waktu. Selanjutnya rasio ini dibandingkan dengan maximum payback period yang telah ditetapkan oleh PT CMM yaitu selama pembangunan proyek atau sampai pada penjualan seluruh produk (unit apartemen), yang dalam hal ini ditetapkan selama 4 tahun. Kaidah yang digunakan dalam pengambilan keputusan pada metode ini adalah apabila payback period yang didapat dari hasil perhitungan lebih kecil dari pada waktu yang telah ditentukan oleh manajemen perusahaan (4 tahun) maka investasi ini dianggap layak.

Pada proyek Apartemen Citralake Suites ini modal awal (initial cash investment)-nya adalah 18,9 Milyar yang dikucurkan dari modal sendiri. Untuk mengetahui berapa lama waktu yang dibutuhkan untuk mengembalikan initial cash investment yang 18,9 Milyar tersebut dapat dilihat melalui tabel Cash Flow bahwa nilai 18,9 Milyar dapat dikembalikan dalam waktu 1 tahun baik dalam skenario normal maupun Optimis jadin dapat disimpulkan proyek ini layak dijalankan.

Dengan perhitungan di atas, berarti payback period untuk penjualan tahun pertama. Semua hasil ini jauh lebih kecil dari ketetapan manajemen yang 4 tahun, dengan demikian proyek ini layak diterima. Tetapi metode payback periode ini sangat sederhana sehingga mempunyai kelemahan. Kelemahan utamanya yaitu metode ini tidak memperhatikan konsep nilai waktu dari uang disamping juga tidak memperhatikan aliran kas masuk setelah payback. Jadi umumnya metode ini digunakan sebagai pendukung metode lain yang lebih baik.

Net Present Value, Untuk menghitung NPV pada proyek ini, penulis menggunakan asumsi-asumsi sebagai berikut : Tingkat bunga yang diperoleh dari Bank sebesar 5\%, dan tingkat bunga Kebijakan pemegang saham terhadap modal sendiri sebesar 10\% maka Weighted Average Cost Of Capital (WACC) yang ditetapkan pada perhitungan NPV sebesar 10\% karena proyek ini $100 \%$ menggunakan modal sendiri (tabel cash revenue).

Dari perhitungan, terlihat bahwa NPV cash inflow masih jauh lebih besar dari pada NPV cash outflow yaitu dengan selisih sebesar

1. Alternatif 1 Normal = Rp. 66,106,145,755,-

2. Alternatif 2 Optimis = Rp. 67,339,989,106,--

Artinya menurut penilaian NPV bahwa proyek ini dianggap cukup layak untuk dilaksanakan dengan alternatif terbaik adalah skenario optimis dikarenakan akan ada kenaikan harga jual.

Internal Rate of Return (IRR), metode ini digunakan untuk mencari tingkat bunga yang menyamakan nilai sekarang dari arus kas yang diharapkan di masa datang, atau penerimaan kas, dengan mengeluarkan investasi awal.

Dari hasil nett cashflow yang ada didapat IRR sebesar :

1. Alternatif 1 Normal $=171 \%$

2. Alternatif 2 Optimis $=180 \%$

IRR alternatif 1 dan 2 lebih besar dari Weighted Average Cost of Capital (WACC), sehingga layak dilaksanakan

Dari beberapa analisis penilaian investasi dengan perhitungan Payback Periode, Net Present Value, Internal Rate of Return dan Profitability Index, kesemuanya menunjukkan bahwa investasi PT CMM dalam rangka Pengembangan Proyek Apartemen Citralake Suites di wilayah Jakarta Barat ini dianggap sangat layak untuk dilaksanakan. 


\section{Saran}

Memperhatikan apa yang telah dianalisis dan dibahas sebelumnya, maka saran-saran yang dapat diberikan dalam tulisan ini adalah sebagai berikut :

1. Dari aspek marketing perlu melakukan "market survey" secara lebih tajam lagi untuk menentukan positioning proyek dan target market serta pengembangan detail product sales yang sesuai dengan kawasan. Pelaksanaan Market Positioning tersebut dijalankan melalui :

- Identifikasi keunggulan kompetitif yang memberikan nilai tambah terbesar dengan cara mengadakan : diferensiasi produk, diferensiasi jasa, diferensiasi personil dan diferensiasi citra.

- Memilih keunggulan kompetitif yang tepat, antara lain dengan mempromosikan apa saja perbedaan yang dimiliki.

- Mewujudkan dan mengkomunikasikan posisi yang dipilih.

- Menggunakan keempat macam sarana promosi yang adalah :

Periklanan (Advertising)

Promosi penjualan (Sales Promotion)

Publisitas (Publicity)

Penjualan kedaerah-daerah (Road Show)

2. Dari aspek teknik, harus mampu memberikan nilai tambah pada produk bangunan yang dihasilkannya, baik mengenai satuan harga dan alternatif spesifikasi material yang digunakan maupun dari sisi metodologi dan kualitas pengawasan dari pekerjaan konstruksi bangunan rumah, pematangan lahan maupun prasarana lingkungan, karena kualitas bangunan dan prasarana lingkungan yang baik dapat meningkatkan nilai jual kawasan tersebut.

3. Dari aspek keuangan, melakukan pengecekan kembali terhadap cashflow yang sudah dibuat disesuaikan dengan strategi pemasaran, pencarian alternatif pendanaan dan monitoring efisiensi pengeluaran biaya-biaya yang muncul selama proyek berjalan.

\section{Daftar Pustaka}

Afifudin, H. 2013. Dasar - Dasar Manajemen. CV. Bandung : CV. Mandar Maju.

Hadi. (2006). Pengaruh Budaya Organisasi dan Iklim Organisasi terhadap kepuasan kerja.

Hasibuan. (2011). Manajemen Sumber Daya Manusia. Jakarta : Bumi Aksara Jakarta : Kencana Robbins, Stephen P. (2013). Organizational Behavior. New York : Prentice Hall PTR.

Scott Rood, Andrew Holdnak. (2013). An Analysis of Compensation Patterns and Job Satisfaction Issues of Resort RecreationProfessional. Journal of Tourism Insights Volume 4, Issue 1 7-23-2013.

Sutrisno, Edy. (2013). Manajemen Sumber Daya Manusia. Edisi Pertama. Cetakan Pertama.

Cooper, Donald R, Pamela S Schindler. (2011). Business Research Method. Edisi 11, The McGraw-Hill Companies, Inc, New York.

Tim PPM Manajemen (2012). Business Model canvas. PPM Manajemen 